READS' OPINION

\section{Final comments on an interesting taxonomic dilemma: Leishmania infantum versus Leishmania infantum chagasi}

\author{
Filipe Dantas-Torres
}

\author{
Departamento de Imunologia, Centro de Pesquisas Aggeu \\ Magalhães-Fiocruz, Av. Professor Moraes Rego s/no, \\ 50670-420 Recife, PE, Brasil
}

\section{Dear Editor,}

It is grateful to see that the new session "Readers' opinion and discussion" created after my comments "Leishmania infantum versus Leishmania chagasi: do not forget the law of priority" (Dantas-Torres 2006) - on the concise review article of Lainson and Rangel (2005) has emerged as the basis of an interesting debate on the aetiological agent of American visceral leishmaniasis, i.e., the taxonomic dilemma concerning its correct nomenclature. Further details of this discussion can be found elsewhere (Dantas-Torres 2006, Lainson \& Rangel 2006). Recently, I was surprised (and very happy as well) to see the welcome contribution of Professor Jeffrey Shaw, a world-leading expert in the field of leishmaniasis. Dr Shaw is a respected reference in classification of leishmanial parasites and I must agree with most of his comments. However, I would like to write my last few words on this matter. In fact, as Lainson and Rangel (2006) previously emphasized, the name Leishmania infantum chagasi entirely follows the rules of the International Code of Zoological Nomenclature. That is correct, but the point is: Is this name according to the current criteria used to classify parasites of the genus Leishmania? What are the criteria?

Among the techniques currently in use for classification of leishmanial parasites are: isoenzyme electrophoresis (WHO 1990), species-specific monoclonal antibodies, DNA probe and analysis of restriction fragment length polymorphism (RFLP) using different DNA sequences as targets (Macedo et al. 1992, Guizani et al. 1994, Mendonza-Leon et al. 1995). As Shaw (2006) commented, recent studies on the Old World visceral parasites using the internal transcribed spacer (ITS) (Kuhls et al. 2005) and fluorogenic assays (Quispe-Tintaya et al. 2005) suggested the need for a taxonomic revision of Leishmania donovani complex. It is clear that the current status of certain Leishmania species (e.g., Leishmania archibaldi) need to be revised (Mauricio et al. 2006).

$\overline{\text { E-mail: fdt@cpqam.fiocruz.br }}$

Postgraduate studentship from $\mathrm{CNPq}$
I have the modest opinion that we should first reestablish (i.e., update) the criteria for the classification of the leishmanial parasites based on the traditional criteria (Lainson \& Shaw 1987) and data from recent molecular investigations. Then it would be easier to agree if a given parasite deserves the status of species or subspecies. But what is a subspecies? In the first chapter of the memorable book The Leishmaniases in Biology and Medicine, Lainson and Shaw (1987) defined subspecies as "local, geographically isolated populations which show some (usually minor) taxonomic differences from other geographically separated populations of the same species". If we take this definition into account, I should agree that the classification of the aetiological agent of American visceral leishmaniasis as Leishmania infantum chagasi is acceptable. The challenge will be to convince other researchers who do not believe that exist taxonomic differences (even minor) between the aetiological agents of visceral leishmaniasis in the Americas and the Mediterranean basin.

Henceforth, I would be happy to see in the current literature the use of a single designation for the aetiological agent of American visceral leishmaniasis. Unfortunately, different names are currently in use, such as Leishmania chagasi (Berman 2006), Leishmania infantum (MoraesSilva et al. 2006), Leishmania infantum chagasi (Lainson \& Rangel 2005), Leishmania chagasi/infantum (Feliciangeli et al. 2005), Leishmania infantum (chagasi) (Bern et al. 2005), and even Leishmania (chagasi) infantum (Barrouin-Melo et al. 2006); and this is scientifically unacceptable. I hope this debate initiated by a young 'leishmaniac' and properly complemented by respected experts in the field of leishmaniasis (Dr Lainson, Dr Rangel, and Dr Shaw) will help researchers who are direct or indirectly involved with taxonomy of leishmanial parasites. Finally, I would like to emphasize the importance of assign a single name for the aetiological agent of American visceral leishmaniasis, which appears to be losing its identity but not its virulence (DantasTorres 2005, Dantas-Torres \& Brandão-Filho 2006).

\section{REFERENCES}

Barrouin-Melo SM, Larangeira DF, de Andrade Filho FA, Trigo J, Juliao FS, Franke CR, Palis Aguiar PH, Conrado-dosSantos WL, Pontes-de-Carvalho L 2006. Can spleen aspirations be safely used for the parasitological diagnosis of canine visceral leishmaniasis? A study on assymptomatic and polysymptomatic animals. Vet $J$ 171: 331-339

Berman J 2006. Visceral leishmaniasis in the New World \& Africa. Indian J Med Res 123: 289-294.

Bern C, Hightower AW, Chowdhury R, Ali M, Amann J, Wagatsuma Y, Haque R, Kurkjian K, Vaz LE, Begum M, Akter T, Cetre-Sossah CB, Ahluwalia IB, Dotson E, Secor WE, Breiman RF, Maguire JH 2005. Risk factors for kalaazar in Bangladesh. Emerg Infect Dis 11: 655-662

Dantas-Torres F 2005. Increasing case fatality rate of visceral leishmaniasis in Brazil. Rev Bras Vigilância Sanitária 1: 260-263.

Dantas-Torres F 2006. Leishmania infantum versus Leishmania chagasi: do not forget the law of priority. Mem Inst Oswaldo Cruz 101: 117-118. 
Dantas-Torres F, Brandão-Filho SP 2006. Visceral leishmaniasis in Brazil: revisiting paradigms of epidemiology and control. Rev Inst Med Trop São Paulo 48: 151-156.

Feliciangeli MD, Delgado O, Suarez B, Chiurillo MA 2005. The burden of the Leishmania chagasi/infantum infection in a closed rural focus of visceral leishmaniasis in Lara state, west-central Venezuela. Trop Med Int Health 10: 444-449.

Guizani I, Van Eys GJJM, Ismail RB, Dellagi K 1994. Use of recombinant DNA probes for species identification of Old World Leishmania isolates. Am J Trop Med Hyg 50: 632640 .

International Commission on Zoological Nomenclature 1999. International Code of Zoological Nomenclature, The International Trust for Zoological Nomenclature, London, 306 pp.

Kuhls K, Mauricio IL, Pratlong F, Presber W, Schonian G 2005. Analysis of ribosomal DNA internal transcribed spacer sequences of the Leishmania donovani complex. Microbes Infect 7: 1224-1234.

Lainson R, Rangel E 2005. Lutzomyia longipalpis and the ecoepidemiology of American visceral leishmaniasis, with particular reference to Brazil -A Review. Mem Inst Oswaldo Cruz 100: 811-827.

Lainson R, Rangel EF 2006. Leishmania infantum versus Leishmania chagasi: do not forget the law of priority: Reply. Mem Inst Oswaldo Cruz 101: 118.

Macedo AM, Melo MN, Gomes RF, Pena SDJ 1992. DNA fingerprints: a tool for identification and determination of the relationship between species and strains of Leishmania. Mol Biochem Parasitol 53: 63-70.
Mauricio IL, Yeo M, Baghaei M, Doto D, Pratlong F, Zemanova E, Dedet JP, Lukes J, Miles MA 2006. Towards multilocus sequence typing of the Leishmania donovani complex: resolving genotypes and haplotypes for five polymorphic metabolic enzymes (ASAT, GPI, NH1, NH2, PGD). Int J Parasitol 36: 757-769.

Mendoza-Leon A, Havercroft JC, Barker DC 1995. The RFLP analysis of the b-tubulin gene region in New World Leishmania. Parasitology 111: 1-9.

Moraes-Silva E, Antunes FR, Rodrigues MS, da Silva Julião F, Dias-Lima AG, Lemos-de-Sousa V, de Alcantara AC, Reis EA, Nakatani M, Badaro R, Reis MG, Pontes-de-Carvalho L, Franke CR 2006. Domestic swine in a visceral leishmaniasis endemic area produce antibodies against multiple Leishmania infantum antigens but apparently resist to $L$. infantum infection. Acta Trop 98: 176-182

Quispe-Tintaya KW, Laurent T, Decuypere S, Hide M, Banuls AL, De Doncker S, Rijal S, Canavate C, Campino L, Dujardin JC 2005. Fluorogenic assay for molecular typing of the Leishmania donovani complex: taxonomic and clinical applications. J Infect Dis 192: 685-692.

Shaw JJ 2006. Further thoughts on the use of the name Leishmania (Leishmania) infantum chagasi for the aetiological agent of American visceral leishmaniasis. Mem Inst Oswaldo Cruz 101: 577-579.

Lainson R, Shaw JJ 1987. Evolution, classification and geographical distribution. In R Killick-Kendric, WPeters (eds), The Leishmaniases in Biology and Medicine, Academic Press, London, p. 1-120.

WHO-World Health Organization 1990. Control of the Leishmaniasis, WHO Tech Rep Ser 793. 